\title{
Documentos y escribanía del cabildo catedralicio de Burgos (siglo XIII)
}

\author{
Pilar Ostos Salcedo * \\ Quia longitate temporis rei conditio sepius ocultatur, idcirco, facta hominum \\ scripture solent memorie comendari ${ }^{\prime}$
}

Frágil es la memoria humana y por ello la necesidad de fijar por escrito los hechos. Resulta incuestionable que los testimonios escritos sirven para dejar constancia de lo acontecido. No de todo, pero si de aquéllo de lo que se quería, o se debía, dejar prueba. Es cierto que el paso del tiempo ha influido en la merma de las fuentes escritas del pasado, a veces por descuido o dejadez, en ocasiones intencionadamente. Pero, si alguna institución se ha caracterizado, en general, por el celo en la conservación de su memoria histórica ha sido, principalmente, la eclesiástica. Monasterios y catedrales constituyen un buen ejemplo de ello, ya que desde muy temprano tuvieron conciencia de su importancia y de la necesidad de su guarda. Además, durante siglos fueron casi los únicos en tener capacidad escritoria y, por consiguiente, recaía en ellos la responsabilidad de plasmar por escrito las obligaciones y acuerdos establecidos por la gran mayoría de la población, incluidos los reyes. Contaban, igualmente, con un punto de referencia básico, los documentos procedentes de la cancillería pontificia ${ }^{2}$, así como con las diferentes reglas y disposiciones que ponian el acento en la escritura y en la escrituración.

La riqueza de los archivos catedralicios, su antigüedad, su importancia y el buen estado de conservación de los documentos que custodian han

Universidad de Sevilla.

Serrano, L., D. Mauricio, obispo de Burgos y fundador de su catedral Madrid 1922, n. 12, págs. 142-143. LizoAIN, J. M., Documentación del monasterio de Las Huelgas de Burgos. Burgos 1985, n. 237, págs. 343-345.

Vid. el reciente artículo de GuYOTJEANNIN, O., "L'influence pontificale sur les actes épiscopaux français", en L'Eglise de France et la Papauté (s. x-xllle siècle). Bonn 1993, págs. 83-102. 
favorecido el frecuente uso y análisis por parte de especialistas de las distintas áreas y materias. Sin embargo, hemos de indicar la casi ausencia de estudios de diplomática episcopal para el área castellano-leonesa ${ }^{3}$, y ello sorprende, pues el obispo por una parte y el cabildo catedralicio por otra, o de manera conjunta, han sido protagonistas de numerosas acciones y hechos que, de carácter jurídico, judicial o administrativo, han necesitado su reflejo escriturario y, en muchas ocasiones, han sido producto de unas oficinas de expedición propias y singulares, que requieren un estudio particular. Cancilleria real y oficinas notariales son los dos grandes centros de producción documental desde la segunda mitad del siglo XIII, pero las que poco a poco fueron creándose alrededor del poder episcopal y capitular también tuvieron su significación y proyección en un mundo y en una época especialmente imbuida del poder religioso y del más allá ${ }^{4}$.

Por otra parte, en el momento actual de los estudios de diplomática castellano-leonesa, los trabajos sobre documentación episcopal de los siglos XII y XIII pueden arrojar datos muy interesantes sobre la fijación del formulario de los documentos reales, especialmente en ciertas fórmulas que, de carácter protocolario -invocaciones verbales y sobre todo preámbulos-o sancionador - cláusulas finales-, pueden tener su precedente en aquéllos, ya que las personas encargadas de la producción documental de los reyes de Castilla y León estaban, en un principio, vinculadas al estamento eclesiástico. Es indudable la presencia del cabildo de Santiago de Compostela en la cancillería leonesa; es detectable la importancia de la diócesis palentina en la cancillería castellana durante el reinado de Alfonso VIII. No seria ilógico pensar en un trasvase de experiencias documentales $y$ de formularios de unas realidades a otras.

El VIII Congreso Internacional de Diplomática, dedicado al análisis de cancillerías episcopales en Europa, me ha puesto en contacto con la

Para cuestiones de carácter general en el área castellana sólo podemos citar tres aportaciones muy diferentes: BarRERo García, A. M., “Un formulario de cancillería episcopal castellanoleonés del siglo XII", en A(nuario) de H(istoria) del D(erecho) E(spañol), XLVl. (Madrid 1976), págs. 671-711. Riesco TerRero, A., "El sello episcopal hasta el Renacimiento. Valoración jurídicodiplomática y archivistica del mismo", en XV Congreso Internacional de Ciencias, Genealogía y Heráldica, lll. (Madrid 1983), págs. 365-390; “Consideraciones en torno a la Diplomática Episcopal antigua y medieval (siglo v-xIII)", en Homenaje al prof. J. Torres Fontes. (Murcia 1988), págs. 1387-1399. A ellos hay que añadir los trabajos presentados en el VIII Congreso Internacional de Diplomática por las dras. Pardo Rodriguez y SAnz Fuentes sobre las diócesis de la Bética y de Oviedo hasta el siglo $x \| I$ respectivamente y que en este momento se encuentran en prensa.

4 Vid. Tock, B. M., Une chancellerie épiscopale au xile siècle: le cas d'Arras. Louvain-le-Neuve 1991; "Auteur ou impétrant? Reflexions sur les chartes des évêques d'Arras au xlle siècle", en Bibliothèque de l'Ecole des Chartes, 149 (1991), págs. 215-248; "Les chartes promulguées par le chapitre cathèdral d'Arras au Xlle siècle", en Revue Mabillon, 2, t. 63 (1991), págs. 49-97. 
documentación episcopal de la diócesis de Burgos anterior a $1300^{5}$. Por vez primera me enfrentaba, de manera particular, a una producción documental protagonizada por el obispo de una diócesis y por los miembros de su cabildo. Interrogantes de carácter conceptual y metodológico surgieron inmediatamente a la hora de llevar a cabo este estudio. Entre ellos, la conveniencia o no de abordar separadamente la documentación protagonizada por el obispo, de aquélla otra intitulada por el cabildo de la diócesis, pues quizá la realidad de una época determinada, sobre todo la inicial, no presentara una dicotomía tan radical como desde un principio se pudiera pensar. Convencida de que un análisis conjunto me podía llevar a la clarificación de ambas realidades, examiné tanto los documentos de los obispos burgaleses como los del cabildo. Y pude comprobar cómo en la tercera década del siglo XIII, coincidiendo con el episcopado del célebre D. Mauricio, las oficinas de expedición del obispo y del cabildo empezaban a ser una realidad diferenciada y diferenciadora de los documentos protagonizados por unos y otros. En este momento, voy a abordar la escribania del cabildo capitular de la diócesis de Burgos a lo largo del siglo XIII, no de su obispo, y basándome, fundamentalmente, en las fuentes documentales publicadas ${ }^{6}$.

"Documentos y cancillería de la diócesis episcopal de Burgos anterior 1300" (en prensa).

- Ál.Amo, J. del, Colección diplomática de S. Salvador de Oña (822-1284), 2t. Madrid 1950 [= Oña]. Castro Garrido, A., Documentación del monasterio de Las Huelgas de Burgos, 3t.: (12841306) (1307-1321) (1322-1328) Burgos 1987 [-= Las Huelgas]. Garcia Aragón, L., Documentación del monasterio de la Trinidad de Burgos (1198-1400). Burgos, 1985 [= La Trinidad de Burgos]. GarRido GaARIDO, J. M., Documentación de la catedral de Burgos t.1: (804-1183), t.2: (1184-1222). Burgos 1983 [= Catedral de Burgos]. Ledesma RuBio, M. L., Cartulario de S. Millán de la Cogolla (1076-1200). Zaragoza 1989 [ = Cartulario de S. Millán]. LizoAIN GARRIDO, J. M. Documentación del monasterio de las Huelgas de Burgos t.1: (1116-1230), t.2: (1231-1262), t.3: (1263-1283). Burgos 1985 y 1987 [= Las Huelgas]. Mansilla Reoro, D., Catálogo documental del Archivo Catedral de Burgos (804-1416). Madrid 1971 [= Catálogo Burgos]. OCEJA GONZALO, I., Documentación del monasterio de S. Salvador de Oña t.1: (1032-1284), t.2: (1285-1310), t.3: (1311-1318). Burgos 1983 y 1986 [= Oña]. PeNAA PÉREZ, F. J., Documentación del monasterio de S. Juan de Burgos (1091-1400), Burgos 1983 [=S. Juan de Burgos]. Pereda Llarena, F. J., Documentación de la catedral de Burgos, t.1: (1254-1293), t.2: (12941316). Burgos 1984 [= Catedral de Burgos]. PÉrez CELADA, J. A., Documentación del monasterio de S. Zoilo de Carrión, t.1: (1047-1300), t.2: (1301-1400). Burgos 1986 [= S. Zoilo de Carrión]. RODRigueZ DE LAMA, I., Colección diplomática medieval de La Rioja, t. II (923-1168), t. III (1168-1225), t. IV: siglo XIII. Logroño 1976, 1979 y 1989 [= La Rioja]. SerRANo, L., Colección diplomática de S. Salvador del Moral. Valladolid 1906 [= S. Salvador del Moran; Cartulario del Infantado de Covarrubias. Valladolid 1907 [ = Infantado de Covarrubias]; Becerro Gótico de Cardeña. Valladolid 1910 [= Cardeña]; Cartulario de S. Pedro de Arlanza. Burgos 1925 [ = S. Pedro de Arlanza]; Cartulario del monasterio de Vega. Burgos 1927 [= Vega]; Cartulario de S. Millán de la Cogolla. Madrid 1930 [= S. Millán de la Cogolla]; El Obispado de Burgos y Castilla primitiva desde el siglo XIII, 3t. Madrid 1935-1936 [= Obispado de Burgos]; D. Mauricio, obispo de Burgos y fundador de su catedral [ = D. Mauricio]; «El cancilier de Fernando ill de Castilla", en Hispania, 3 (Madrid 1943), págs. 557-579 [= El canciller]. UBieto ARTETA, A., Colección diplomática de Cuéllar. Segovia 1961 [ [ Cuéllar]. Vivancos Gómez M. C., Documentacion del monasterio de Santo Domingo de Silos. Burgos 1988 [= Silos]. 
La restauración eclesiástica de la antigua diócesis de Oca, pero fijada en Burgos, tuvo lugar en el año 1068 y fue confirmada por Gregorio VII años más tarde, en 1074. Antes de que terminara esta centuria -en 1096-, Urbano II la declara exenta y por tanto dependiente directamente de Roma ${ }^{7}$, quebrando así las pretensiones de las diócesis de Toledo y Tarragona. Imbuida, desde un principio, de los tiempos de reforma y de unificación que propugnaba la autoridad papal, Burgos pasó a ser una sede episcopal de gran importancia en el reino castellano. Por una parte, su gran extensión geográfica ${ }^{8}$, su situación y organización: estaba subdividida en seis arcedianazgos (Burgos, Briviesca, Lara, Palenzuela, Valpuesta y Treviño), que tenían jurisdicción ordinaria y éstos en arciprestazgos, así como en ocho abadías (Castrojeriz, Cervatos, Foncea, S. Millán de Lara, S. Quirce, Salas de la Bureba, Castañeda y S. Martín de Helines), que también gozaban de una jurisdicción análoga. Además había otras tres abadías casi exentas (Covarrubias, Santander y Santillana del Mar) ${ }^{9}$.

Pero, fundamentalmente, el especial apego que los monarcas castellanos tuvieron con esta ciudad justifican este papel relevante a lo largo del siglo xII y primera mitad del XIII. Tanto Alfonso VIII como su nieto Fernando III regresaban a esta ciudad tras las largas campañas emprendidas y, por tanto, es lógico que gozara de un favor singular. La fundación del cisterciense monasterio de Las Huelgas por parte del primero y la celebración de sus dos enlaces matrimoniales en la catedral de Burgos por parte del segundo pueden ser muestra de ello. No queda atrás el peso religioso, espiritual y hasta político que tuvieron los prelados que la presidieron durante esta época, fundamentalmente en la primera mitad del siglo xIII: D. Mauricio ${ }^{10}$ (1213-1238) y D. Juan ${ }^{11}$ (1240-1246), canciller que fue de Fernando liI. Tras una sucesión de breves mandatos episcopales, destaca de nuevo Gonzalo García de Gudiel (1275-1280), quien primero

Vid. Serrano, L., Don Mauricio, pág. 17. Tanto este autor como D. Mansilla ponen de manifiesto las ingerencias del poder real en la elección del prelado burgalés (vid. ibidem, pág. 18). Mansilla, D., Iglesia castellano-leonesa, págs. 175-177. LineHan, P., La iglesia española y el Papado en el siglo xill. Salamanca 1975, págs. 97-98.

a Actuales provincias de Santander y Burgos, extendiéndose hacia La Rioja, Álava y Vizcaya por el este y por el oeste hacia Palencia, León y Asturias. (Vid. SeRrano, L., El obispado de Burgos, pág. 231. Historia de la lglesia de España, dir. por GARCía DE VILLOSLADA, R. t. II-2, págs. 630-631. Diccionario Eclesiástico de España, t. I, pág. 290).

- Vid. Serrano, L., Don Mauricio, págs. 12-13.

Vid. Serrano, L., Don Mauricio.

Vid. Serrano, L., “El canciller del Rey», en Hispania. Millares, A., "La cancillería castellano-leonesa hasta Fernando III", en AHDE, Ill (1926), pág. 283. GonZÁLEZ J., Reinado y diplomas de Fernando III, t. I. Córdoba 1980, págs. 504-509. 
fue notario mayor de Castilla y después, al ocupar la metrópolis toledana, alcanzó, como era preceptivo ya en esa época, el cargo de canciller del reino castellano ${ }^{12}$. Termina la centuria con el prolongado gobierno de fray Fernando (1280-1299), que falleció siendo obispo de esta sede.

\section{LA COMPOSICIÓN DEL CABILDO Y SU OFICINA DE EXPEDICIÓN DOCUMENTAL}

Durante el siglo XII, los documentos emanados por el titular de la diócesis reflejaban la cada vez mayor presencia de su cabildo catedralicio a la hora de la testificación, tanto en su frecuencia como en el número y título de dignidades y demás miembros que, poco a poco, van conformándolo ${ }^{13}$, pudiendo observarse cómo al final de esta centuria estaba compuesto por un mayor número de personas: "prior" al principio y "deán" a partir de 1189, arcedianos —normalmente tres-, "sacristán" desde 1139, "capiscol» en 1161 y "cantor" desde 1168, "mayordomos» a partir de la misma fecha, "capellán", "arciprestes" y upreceptor" desde 1174. Todos ellos se repiten, siguiendo normalmente un orden de prelación en su relación, junto con el nombre de diferentes canónigos y la alusión general al cabildo. La separación de la mesa episcopal y catedralicia empieza a ser una realidad a partir del siglo xII, cuando los miembros del cabildo quieren deslindar sus propiedades de las del obispo, y ello es algo que en cada diócesis se va a dar en un momento determinado ${ }^{14}$.

12 Vid. Lopez Gutiérez, A., La cancillería de Alfonso $X$ a través de las fuentes legales y la realidad documental. Ed. en microfichas. Oviedo 1991.

13 Serrano, L., El Moral, n. VII, págs. 41-45; Obispado de Burgos, n. 127, pág. 211; n. 128, pág. $212 ;$ n. 133, págs. 222-223; n. 140, págs. 232-234; n. 143, pág. 238; n. 149, págs. 245-246; n. 150 , págs. $246-247$; n. 152 , págs. $248-250$; n. 163 , págs. $265-266$; n. 182, págs. 289-290; n. 211 , págs. $330-332$; n. 215, págs. 355-356. ÁlaMO J. del, Oña, n. 212, págs. 256-257. GarRiDo, J. M., Catedral de Burgos, n. 149, pág. 247; n. 157, págs. 256-257; n. 158, págs. 257-258; n. 168 , págs. $271-272$; n. 175 , págs. $282-284$; n. 177 , págs. $286-287$; n. 189, págs. 300-302; n. 190 , págs. $302-303 ; n$. 193 , págs. $306-307 ;$ n. 214 , págs. $329-331$; n. 218, págs. 336-337; n. 252, págs. $18-20 ; n$. 255, págs. 22-23; n. 315, págs. 103-104; n. 237, pág. 117. LeDESMA, M. L., Cartulario de S. Millán, n. 401, págs. 285-287. LizOAIN, J. M., Las Huelgas, n. 24, págs. 46-48. PENA, F. J., S. Juan de Burgos, n. 46, págs. 65-67; n. 56, págs. 78-79.

${ }_{14}$ Vid. Mansilla, D., Iglesia castellano-leonesa, págs. 193-194. Vid. Casado, H., La propiedad eclesiástica en la ciudad de Burgos en el siglo xv: el cabildo catedralicio. Valladolid, 1980, pág. 44. En líneas generales, a la mesa capitular le corresponden los préstamos de la zona sur y de los alrededores de la ciudad, mientras que los del obispo se sitúan más bien al norte. La mesa episcopal seria administrada en lo espiritual y económico por el prelado y sus mayordomos y la del cabildo por sus mayordomos o racionero (vid. SerRano, L., Don Mauricio, pág. 13). 
Los autores materiales de documentos protagonizados por el obispo o por el cabildo durante este siglo XII son, por lo general, los mismos. Si ello supusiera su vinculación exclusiva a una posible cancilleria eclesiástica, algo que ponemos en duda en estos casos, nos indicaría que en esta época no estaba delimitada y separada la producción documental del obispo y del cabildo catedralicio. Entre éstos, destaca lohannes Saturnini, que, sin expresar título alguno, fue responsable de ciertos documentos del obispo y un censo de su cabildo ${ }^{15}$, todos ellos alusivos a la administración de propiedades, pero que también puso por escrito documentos de otras personas de la ciudad. Dionisius confeccionó una concordia episcopal y un prestimonio capitular ${ }^{16}$; y Parisius, el acuerdo establecido entre el cabildo de Burgos y los hijos del que fuera prior de dicha iglesia ${ }^{17}$.

Tres momentos fundamentales se pueden detectar en la reglamentación interna de este cabildo catedralicio a lo largo del siglo xIII: la constitución de D. Mauricio de 1230, la del cardenal Gil Torres, confirmada por Inocencio IV en 1252, y, en menor medida, los acuerdos capitulares elaborados por el propio cabildo en 1291.

La primera, la llamada constitución «mauriciana», reglamentaba, principalmente, la obligatoriedad de asistencia al coro de todos los miembros del cabildo burgalés, su distribución en él ${ }^{18}$, la compostura debida a la hora de estos oficios divinos y otros en general. Quizá la desfavorable opinión que en este aspecto emitiera el legado pontificio, Juan de Abbeville, en su visita a la Península en 1228 sobre esta diócesis fuera su inmediata causante ${ }^{19}$. Deán, cantor, sacristán, ocho arcedianos, dos abades y treinta canónigos son los miembros del cabildo citados en ella.

La segunda, la promulgada por el activo cardenal Gil Torres ${ }^{20}$, similar a las dadas pcr él mismo para otras ciudades castellanas -Ávila, Calahorra, Salamanca y Segovia-, es mucho más explícita en cuestiones relativas a

15 Serrano, L., Obispado de Burgos, n. 150, págs. 246-247.

16 Garaido, J. M., Catedral de Burgos, n. 327, pág. 117.

17 GarRido, J. M., Catedral de Burgos, n. 255, págs. 22-23. En la relación de miembros del cabildo burgalés, en la primera columna de un documento de 1184 , hay una suscripción de un tal Parisius.

18 A la derecha del coro y por este orden: el deán, cantor, los arcedianos de Valpuesta y de Treviño, el sacristán y los abades de Foncea y de Cervatos. A su izquierda: los arcedianos de la ciudad, de Briviesca, de Lara, de Palenzuela, de Salas de los Infantes y de $S$. Quirce.

19 Vid. Serrano, L., D. Mauricio, págs. 140-141. Linehan, P., op. cit., págs. 17-47. Costa $\gamma$ BELDA, E., "Las constituciones de D. Raimundo de Losaña para el cabildo de Sevilla (1261)", en Historia. Instituciones. Documentos, 5. (Sevilla 1978), págs. 190-191.

zo Vid. Serrano, L., D. Mauricio, págs. 70-73. Mansilla, D., Iglesia castellano-leonesa, pág. 196. Linehan, P., Op. cit, págs. 243-263. 
la composición del cabildo, obligaciones de cada uno, forma de elección e incluso emolumentos designados para su sustento. El deán debía ser elegido por el obispo y por el cabildo de mutuo acuerdo, percibiendo por sus funciones la cantidad más elevada $-700 \mathrm{mrs}$. - ; el arcediano de la ciudad recibiría $500 \mathrm{mrs}$.; el cantor y cada uno de los otros arcedianos, $400 \mathrm{mrs}$.; al igual que el sacristán, que también se beneficiaría de unas rentas que D. Mauricio había fijado con anterioridad; a tal cantidad, los abades de Castrojeriz, Foncea y Salas de los Infantes añadirian los derechos que tenian asignados; los otros tres abades percibirian las rentas de sus propias abadías; cada canónigo, $80 \mathrm{mrs}$.; los porcioneros mayores, $40 \mathrm{mrs}$. y los menores, la mitad. El cabildo designaba, además, a un doctor en órgano, el cual recibia también $400 \mathrm{mrs}$. por su trabajo ${ }^{21}$. Son mencionados, finalmente, diez niños para el coro ${ }^{22}$.

Causa sorpresa, sin embargo, que ni en estos estatutos, ni el los anteriores, haya sido contemplada la figura del "maestrescuela", dignidad presente en la mayoria de los cabildos capitulares, obligatoria según el IV concilio de Letrán, al que asistió $\mathrm{D}$. Mauricio, y con unas funciones muy relacionadas con el mundo de lo escrito y de la enseñanza, de tal manera que suele estar bajo su competencia la redacción de los documentos de su cabildo e incluso es considerado el canciller del mismo ${ }^{23}$. Dado que el cabildo capitular de Burgos no contaba con esta figura, cabría preguntarse cuál de las otras dignidades seria la encargada del hecho documental.

Los estatutos de 1250 indican, por una parte, que el deán debia ser el depositario del sello del cabildo y el responsable de sellar, con el consentimiento de la mayoría de sus componentes, los documentos capitulares:

“Ordinamus quoque quod ad decus et decorem Burgensis ecclesie novimus pertinere, ut doctor in organo semper sit in eadem ecclesia per capitulum eligendus, cui prestimonium quadraginta morabetinorum assignari mandamus; et tam ad pulsanda organo consuetis solempnitatibus, quam reparanda, aliud viginti morabetinorum prestimonium assignetur a sacrista burgensi tenendum ad hunc usum utiliter dispensandum" (vid. MANSILLA, D., Iglesia castellano-leonesa, pág. 63).

${ }_{22}$ Vid. Mansilla, D., Iglesia castellano-leonesa, págs. 212-214. Costa Y Belda, E., Op. cit., pág. 197. CASADO, H., Op. cit., págs. 33-36

${ }_{23}$ P. 1, 6, 7. Tampoco es mencionado en las constituciones de Calahorra el maestrescuela, siendo extraño, en opinión de D. Mansilla, su omisión en ambas, dada su importancia (Vid. Mansilla, D., Iglesia castellano-leonesa, pág. 199 y 204. Costa y BeLdA, E., Op. cit., pág. 188 y 204). En otro sentido, $G$. Brunel llama la atención sobre la posible relación existente entre la cancillería episcopal y la escuela catedraiicia (vid., BRUNEL, G., "Chartes et chancelleries épiscopales du Nord de la France au XI siècle», en A propos des actes d'évêques. Hormmage à L. Fossier. Nancy 1991, págs. 240-242). En Burgos había una escuela catedralicia, como en la mayoria de las sedes, y de hecho muchos de los componentes del cabildo se titulaban magister, pero, desgraciadamente, no podemos establecer esa relación, aunque creemos que es una idea a tener muy en cuenta. 
"Ad hec cum ad Decanum pertineat custodia sigilli capituli, fideliter ac diligenter possideat ut in litteris capituli sigillandis consensus capituli vel maioris et sanioris partis ibidem residentium presentialiter habeatur et in arduis negotiis ad sigillandas huius litteras, qui fuerint in diocesi convocentur" ${ }^{24}$. La reglamentación de 1291 insiste sobre la cuestión del sellado y las competencias del deán en primera instancia y del cabildo, en segunda: "Otrossí, tenemos por bien que sobre las cartas que fueren de seellar con el seello del cabildo, que si el deán, que ha de tener el seello del cabillo, pudiere venir al cabillo, que traya el seello al cabillo e que allí faga seellar las cartas que el cabildo mandaren. Et si el deán non pudiere venir a cabillo, que el cabillo embíe dos companneros al deán con las cartas e él que los faga seellar antellos. Et si por auentura se acaesciesse que el deán se ouiesse de yr fuera del obispado, que antes que se parta de Burgos traya el seello al cabillo, e el cabillo quel faga guardar fasta que venga el deán, e quando viniere quel den el seello" ${ }^{25}$.

Sobre el "cantor", "chantre" o "capiscol", en 1250, se especifica, detalladamente, su responsabilidad a la hora de seleccionar los componentes del coro, así como en el correcto desarrollo del canto y de los oficios divinos, sin que se le pueda relacionar directamente con la elaboración de los documentos capitulares. Con todo, L. Serrano señala que era «al propio tiempo canciller del cabildo» ${ }^{26}$.

Por el contrario, el «sacristán» era el encargado de la custodia de todos los tesoros de la catedral, entre los que son citados, de manera expresa, libros, privilegios e instrumentos. Precisamente, esta regulación del cabildo va a ordenar la confección de un inventario general de tales tesoros y tras ello, su devolución a la sacristía de la catedral, lugar en el que debían ser convenientemente conservados ${ }^{27}$. El hecho de que estos privilegios y

${ }_{24}$ Vid. MANSILLA, D., Iglesia castellano-leonesa, pág. 364. En Ávila ocurria lo mismo, sin embargo en León y Santiago su custodia recaía en el maestrescuela (lbidem, pág. 203). Según las constituciones dadas por D. Remondo a la iglesia sevillana, el deán debía guardar una de las dos tablas del sello y la otra el maestrescuela (vid. Costa y Belda, E., Op. cit., pág. 200 y 224. Vid. también PARdo Rodriguez M. L., “Las cancillerías episcopales de la Bética antes de 1300» (en prensa).

25 Pereda, F. J., Catedral de Burgos, n. 262, págs. 322-325.

26 Vid. Serrano, L., Obispado de Burgos, t. II, pág. 203.

27. "Ad vitandum quoque dampnum atque periculum Burgensis ecclesie circa privilegia et alia instrumenta ipsius, que per incuariam aliquotiens ad manus extraneas devenerunt, volumus et mandamus ut convocato ad hoc specialiter capitulo generali et presente domino episcopo fiat inventarium totius thesaurii omnium librorum, instrumentorum, privilegiorum, ornamentorum ecclesiasticorum, balsami reliquiarum et omnium que ad instructionem et decorem Burgensis ecciesie pertinent ac ea diligenter conscripta et per certas personas inspecta a Capitulo deputatas, in sacrario Burgensis ecclesie reponantur sub sacriste cura ac sollicitudine fideliter conservanda" (vid. MANSILLA, D., Iglesia castellano-leonesa, pág. 365). 
documentos sean considerados tesoros de la catedral, de que se ordene la elaboración de un inventario y de que, como se recoge más adelante, los originales no fueran exhibidos nada más que lo estrictamente necesario ${ }^{28}$, nos muestra cómo, a mediados de este siglo XIII, se tenía clara conciencia de la importancia y del valor de los documentos, así como de la necesidad de su correcta conservación, bajo la custodia de una de las dignidades del cabildo catedralicio -el sacristán-y encerrados bajo tres llaves, repartidas entre el obispo, el sacristán y una tercera persona de confianza ${ }^{29}$.

Así pues, el sacristán ejercía, entre otras obligaciones, la de archivero y, por consiguiente, estaba relacionado con el hecho documental, si bien no en el proceso de elaboración, sí en el de guarda y custodia de los documentos. En este sentido, las fuentes documentales nos informan, desde 1222, de la existencia de un "armario" donde debian ser conservados aquéllos tocantes al cabildo - «aliud debet in burgensi armario conseruari; quintum in Burgense armario seruatur" ${ }^{30}$-, o más adelante, en 1292, de un "arca" - «esta carta sobredicha es puesta en el arca del comunal» ${ }^{31}$ - a partir de 1225, es el "sacrario" y "sacristía» el lugar señalado como archivo de la catedral: "alia in sacrario Burgensis ecclesie debeat remanere; e la otra deue seer guardada en la sacristanía de Santa María de Burgos» ${ }^{32}$. E incluso se puede deducir la existencia de una ordenación archivística atendiendo a la importancia de su otorgante y de su contenido. Ello explica que cuando D. Mauricio elabora su famosa constitución de 1230 y se hacen dos ejemplares partidos por $\mathrm{ABC}$, en el anuncio de validación se indique que "una permanebit in sacristia perpetuo cum aliis instrumentis ecclesie, altera conservabitur in archis pontificalibus" ${ }^{33}$. Pero además, y ello es un dato muy interesante, se observa cómo, también en 1230, los documentos del cabildo se conservaban en la citada sacristía, mientras que

\footnotetext{
${ }_{28}^{28}$ "Originalia vero nequaquam passim ostendatur nisi neccessitas id exposcat coram certis personis ab episcopo et capitulo deputatis» (vid. MANsilla, D., Iglesia castellano-leonesa, pág 366).

"Originalia vero privilegiorum et instrumentorum Burgensis ecclesie in Sacristia sub tribus clavibus recondantur, quarun unam teneat episcopus, alia penes sacrista remaneat, tertia alicui persone de Capitulo fide digne per capitulum commitatur" (vid. MANSHLA, D., Iglesia castellano-leonesa, pág. 366).

30 Serrano, L., D. Mauricio, n. 8, págs. 134-136; n. 9, págs. 139-140. Rodriguez de Lama, I., La Rioja, III, n. 490, págs. 274-278. GaRRido, J. M., Obispado de Burgos, n. 544, págs. 383-385. Mansilla, D., Catálogo Burgos, n. 573, pág. 150.

31 Pereda, F. J., Catedral de Burgos, n. 276, págs. 347-348.

32 Serrano, L., D. Mauricio, pág. 103. Álamo, J. del, Oña, n. 439, págs. 541-543. Mansilla, D., Catálogo Burgos, n. 657, pág. 169.

33 Serrano, L., D. Mauricio, n. 13, págs. 143-147.
} 
los pertenecientes al obispo eran guardados separadamente: "vnum reponitum fuit in sacristía Burgensi et aliud debet habere episcopus" ${ }^{34}$. Ya en esas fechas, por consiguiente, existía esa separación entre cabildo y titular de la diócesis a la hora de archivar los documentos tocantes a uno y otro, costumbre que vuelve a ser mencionada en 1264: "e la vna destas cartas tiene el cabildo e la otra tenemos nos [= el obispo]" ${ }^{35}$. Quizá, entonces, esta misma distinción pudiera contemplarse a la hora de su elaboración y, por tanto, hubiera ya, en esas mismas fechas, una doble oficina de expedición documental.

El deán como custodio del sello capitular y el sacristán, de sus documentos, son las dos dignidades que aparecen relacionadas con el hecho documental de una manera clara, tanto en los estatutos y normativas establecidas a lo largo del siglo XIII, como en las referencias obtenidas de los propios documentos. Sin embargo, insistimos, no contamos con una mención nítida y taxativa de esa dignidad eclesiástica encargada de la elaboración de los documentos capitulares, como podría deducirse de la figura del maestrescuela en otras diócesis. Ante esta situación, cabria cuestionarse si otra diferente asumía estas funciones documentales - icapiscol? - o bien contaban con un notario de la ciudad para ello, a la que pagarían sus emolumentos correspondientes. Por otra parte, en la relación de miembros del cabildo que testifican algunos documentos son citados Dominicus, scriba en 1206 y lohannes scriba, o lohannes Michael, escriuano, de 1209 a 1222, que también ejerció de mayordomo en 1210 y 1214. Es posible que tuvieran cierta vinculación con la confección de éstos y otros documentos, aunque no exista una mención expresa.

Pero, la serie de permutas, censos y prestimonios existentes de los primeros años de esta centuria, hasta 1222, suelen aportar el nombre de su autor material, coincidente, en muchas ocasiones, con los que formalizaron negocios protagonizados por vecinos de la ciudad, que nada tenían que ver con el cabildo catedralicio: lohannes de Riolazedo de 1200 a 1206, Nicolaus de 1207 a 1210, existiendo un Nicholaus Martini de 1214 a $1220{ }^{36}$, Dominicus Petri y Dionisius en 1209 y lohannes Petri en 1222. No sólo el contenido de estos documentos, sino también la ausencia de sello y la presencia de las citadas suscripciones nos informan que todavía, en esos años, no contaba el cabildo con una escribanía singularizada. A partir de entonces, hay que tener en cuenta que la utilización del sello

34 Mansilla, D., Catálogo Burgos, n. 580, págs. 151-152

35 Pereda, F. J., Catedral de Burgos, n. 66, págs. 92-93.

${ }^{36}$ El capellán del obispo d. Mauricio, en 1221, también se llamaba Nicolaus. 
como medio de validación va a incidir en la omisión frecuente del autor material y, por consiguiente, se carecen de datos seguros de las personas que los escribian. Sin embargo, ello es a su vez un hecho cierto de la existencia de una oficina propia de expedición documental. Excepciones hay y en 1245, la prórroga establecida por el deán de la catedral para la solución de una contienda con el monasterio de Oña, aunque iba validada mediante sello, también añade el nombre del amanuense, un clérigo, de la catedral: «Et ego Bartholomeus, clericus Burgensis, ad acta iudicii scribenda deputatus, notaui omnia et singula prout superius sunt expressa» ${ }^{37}$.

Una vez que el notariado público está ya implantado en la corona castellano-leonesa, el cabildo catedralicio acude, en ocasiones, a los escribanos públicos de su ciudad para que den fe y autenticidad de ciertos hechos y actuaciones de carácter estrictamente eclesiástico, como son fundaciones de hospitales y las confirmaciones de la elección del prior de varios monasterios: «Et ego lohannes Gundisalui, publicus in ciuitate et diocesi burgensi regia auctoritate notarius iuratus, qui una cum dictis testibus interfui et de mandato dictorum decani et capituli hoc publicum instrumentum inde confecti signoque meo solito consignaui (signo)" ${ }^{38}$. En este sentido, y en una recopilación de estatutos y disposiciones del cabildo catedralicio, éste acuerda, el 23 de marzo de 1331, recibir "por su escriuano a Fernando Díaz, escriuano público de Burgos", que era a su vez criado del obispo, y darle la escribanía "assí como la tenía Johán Gonçalez" ${ }^{39}$. Este último, "escriuano publicó por el rey en la çipdat de Burgos» ${ }^{40}$, fue el encargado de poner por escrito, en 1299, las citadas confirmaciones, por parte del obispo y cabildo, de la elección del abad de un monasterio. Por su trabajo, acordaron pagar a Fernando Díaz, de la mesa capitular, "cient maravedís de vestiario cada anno e XXIII fanegas de trigo anuales" ${ }^{41}$. Ello nos lleva a pensar que, por lo menos a finales de este siglo, la escribanía del cabildo era desempeñada por un notario de la ciudad, si bien la realidad anterior sigue quedando silenciada. Evidentemente, habría que añadir los negocios que, como ventas, censos o testamentos, entre otros, entran de lleno en el ámbito de actuación del notariado público.

Vid. Álamo, J. del, Oña, doc. n. 502, págs. 615-617.

38 Pereda, F. J., Catedral de Burgos, n. 344, págs. 78-79.

${ }_{33}$ Ibidem, n. 353, pág. 97.

40 Ibidem, n. 235, págs. $52-53 ;$ n. 340 , págs. $70-72$.

4. Seria interesante revisar los distintos libros de Contabilidad conservados para analizar la existencia de tales pagos o de otros que pudieran realizarse a ciertas personas o por conceptos relacionados con la confección documental. Según J. Pereda, la serie de estos libros se inicia en 1266 (vid. Pereda, F. J., Catedral de Burgos, n. 82, págs. 118-119). 
En 1326, el cabildo reguló la lectura anual de todos los privilegios que poseía la igiesia de Burgos y sus capitulares, para que todos sus miembros fueran conocedores de sus derechos y prerrogativas ${ }^{42}$. En época más avanzada, en 1374, fue establecido que el cabildo se reuniera dos veces por semana -lunes y viernes-, disponiendo que el escribano recogiera todos los acuerdos capitulares por escrito ${ }^{43}$, y durante el siglo xv, según hace constar $\mathrm{H}$. Casado, el cabildo contaba con un escribano mayor y otros dos del consistorio. El primero, notario eclesiástico, vio aumentado considerablemente sus emolumentos a lo largo de dicha centuria, pues de los $465 \mathrm{mrs}$. que percibía al inicio, pasó a $2.465 \mathrm{mrs}$. a finales de la misma. Los segundos también vieron quintuplicar su sueldo en dicho período, pero éste era considerablemente menor, de $100 \mathrm{mrs}$. pasó a 500 mrs. en $1461^{44}$.

La utilización del sello capitular como único elemento de validación es uno de los síntomas claros e inequívocos, en principio, de existencia de una oficina de expedición de documentos, aunque la cautela no debe ser abandonada, pues su confección material pudo ser realizada fuera y haber sido completada en ella. Sin embargo, va a coincidir con la fijación de sus fórmulas diplomáticas, algo que veremos más adelante. La primera referencia de existencia de este sello procede de 1217; del año siguiente son las relativas al sello del deán y del cantor. El obispo, por el contrario, hacía uso de sello desde una época bastante anterior, ya que se retrotrae a los años centrales del siglo xII -1152-. Los sellos conservados, íntegros o más bien de manera fragmentaria, los numerosos anuncios de validación y, en ocasiones, las descripciones aportadas por notarios posteriores nos informan que la forma del sello capitular cambió a lo largo de esta centuria, no asi el tipo representado, y que varió, igualmente, su modo de aposición.

Siempre de cera natural, en un principio adoptó la forma habitual en medios eclesiásticos, es decir, la de doble ojiva y de una sola impronta,

\footnotetext{
42 "Sábado, VIII dias de nouiembre, era de mil e CCC LXIIII annos, anno Domini M CCC XXVI... ordenaron que los priuilegios que ha la yglesia de Burgos, assi los antigos priuilegios commo los nuevos que dieron el emperador e los reyes de Castiella que an seido fasta este dia de oy sobredicho, que se lean cadia anno en cabilldo. Et que los comiençen a leer terçer dia después de la fiesta de Todos Santos fasta que sean acabados, porque los benefiçiados, personas, canónigos, racioneros e medios sepan las libertades e franquezas que la yglesia de Burgos ha de los dichos Emperador e reyes, porque sepan e sean enformados cada que mester fuere para dezir, razonar e defender los derechos de la dicha yglesia de Burgos" (PEREDA, F. J., Catedral de Burgos, n. 353, págs. 102-103).

43 Ibidem, pág. 108.

44 Vid. CaSADO, H., Op. cit., págs. 94-95.
} 
pero a partir de 1291 tenemos constancia de otro circular y con doble impronta. En ambos, el tipo representado es común y es el característico de los cabildos catedralicios, bajo advocación mariana, la mayoría. Se trata, por consiguiente, de una Virgen sedente. Cuando adopta la segunda forma y deja de ser de una sola impronta, el reverso, recubierto de una capa de cera verde, representa una torre y un castillo ${ }^{45}$. La cinta empleada para su suspensión no variaba de la utilizada por el obispo, lino trenzado de color marrón, amarillo y blanco al principio y después azul y blanco.

Otra novedad se puede detectar en los últimos años de la centuria, vinculada a la materia escritora empleada. Me refiero al papel y al sello adherente o placado. La copia certificada realizada por Juan Pérez, escribano público de Burgos, cinco días más tarde de la fecha del original -1295, diciembre 2-, describe minuciosamente la forma y tipo representado en este sello capitular, también redondo y mariano, aunque en este caso representando la coronación de la Virgen María por Jesucristo: "carta abierta escripta en paper, seellada en las espaldas con un seello redondo en que estauan dos ymágenes, la una de lesu Christo e la otra de Santa María, e la de lesu Christo pone una corona con la mano en la cabeça de la imagen de Santa María e en la otra mano tiene figura de libro, e la imagen de Santa María tiene amas las manos ayuntadas ante los pechos, e están amas las ymágines asentadas, e las letras del seello diçen: "S. capituli burgensis ecclesie" "46. Consta, además, que el vicario general del obispo de Burgos usó el sello de placa de cabildo en 1285 y, por los restos que quedan, el color de la cera era verde ${ }^{47}$.

Son frecuentes, por otra parte, las menciones a los sellos personales de las diferentes dignidades del cabildo catedralicio burgalés. Destacan, como es lógico, las referidas a su deán, pero no se quedan muy atrás las correspondientes a sus arcedianos. Entre todos los documentos de este período sobresale uno de 1291, que recoge unos acuerdos de reglamentación interna establecidos por el deán y el cabildo de manera conjunta, pues las 51 suscripciones, repartidas en cuatro columnas, que validan este texto acompañan su intervención autógrafa con la aposición de su sello personal. Aunque no se conserva el original, el anuncio de validación ya pone de manifiesto tal hecho «-e por mayor firmedumbre scribimos cada vno de nos nuestros nombres en esta carta con nuestras manos en testimonio e pusiemos en ella nuestros seellos, cada vno de

45 Pereda, F. J., Catedral de Burgos, n. 262, págs. 322-325.

46 Ibidem, n. 314, págs. 38-39.

47 Serrano, L., Covarrubias, n. 77, págs. 120-121. 
nos del que vsamos en testimonio de verdat" ${ }^{48}$ - y la frase «propia manu subscripsi et sigillum meum apposui» completa cada nombre.

Como hemos señalado, de la escribania del cabildo capitular del Burgos, en la época que estamos analizando, tenemos certeza en dos aspectos. La custodia del sello correspondia a su dignidad más elevada -el deán- y la de los documentos que debian conservar, al sacristán ${ }^{49}$. Sin embargo, no deja de sorprendernos, y volvemos a insistir sobre tal hecho, la ausencia del maestrescuela en este cabildo, ya que, como se sabe, su figura fue impuesta en el Lateranense IV y alli estuvo D. Mauricio ${ }^{50}$. Ni las diferentes reglamentaciones del cabildo, ni los documentos informan sobre quién recaía el peso de su producción y, no obstante, no dudamos de la existencia de esta oficina propia a partir de $1222^{51}$. Si ello no ocurrió, habría, quizá, que pensar que más que un incumplimiento de una disposición conciliar, se trataría de que tales necesidades - educación y elaboración de los documentos- estaban ya resueltas dentro del propio cabildo. Pero ¿por quién? La actividad de la escuela catedralicia proporcionaría personas aptas y capaces de llevar a cabo estas funciones, muchos son los clérigos que anteceden su nombre con el título de magister, testamentos de canónigos y dignidades de esta iglesia, como el del chantre Garci de Campos ${ }^{52}$

4a Pereda, F. J., Catedral de Burgos, n. 263, págs. 325-329.

49 Según $\mathrm{H}$. Casado en el siglo xv existía un guardián del sello y de las llaves del arca de los privilegios (vid. CASADO, H., Op. cit., pág. 95).

so Poco tiempo después, en 1228 , el Concilio de Valladolid, convocado por el cardenal obispo de Sabina, D. Juan de Abbeville, legado de Gregorio IX, y al que también asistió D. Mauricio, con una destacadia actuación, intentó precisar varios cánones del III y IV Concilio de Letrán, sobre todo to referente al estudio de las letras sagradas y teología (vid. Serrano, L., D. Mauricio, págs. 79-81).

${ }^{51}$ Según se desprende de la introducción previa a la edición de los documentos conservados en los archivos de la catedral y de la diócesis de Salamanca, el obispo y cabildo de esta sede salmantina contaban, a fines del siglo XIII, con una notaria propia, semejante a la de León y Zamora (vid. Marín, J. L., Documentos de los Archivos catedralicio y diocesanos de Salamanca (siglo XII-Xill). Salamanca 1977).

52 El testamento del chantre de la catedral Garci de Campos, fechado entre 1267 y 1274 , menciona una serie de libros de derecho de su propiedad: "Los míos Decretos e las Decretales... vn libro de Razones, e los Casos del Derecho e de las Decretales"; asi como religiosos y liturgicos: "quatro pares de Sermones, vn libro vbi sunt Actum Apostolorum, Apocalipsis et Epistole Canonice en vn volumen, Libri Salomonis en otro volumen, Duodecim Prophete en otro volumen, Duodecim Prophete en otro volumen, vn lob sin tablas, vna Biblia en dos parte". Además añade otro conjunto de libros, para que fueran vendidos por su albaceas testamentarios para cumplimiento de su testamento: "vn misal, vn epistolero, vn antiphonario, vn oficiero, dos libros de horas, dos psalterios, vnas Costumbres, vn libro de los Fueros". Tenia también dos libros empeñados en manos del sacristán don Gonzalo y otros obraban en su poder en calidad de préstamo del que por aquella época era obispo de Córdoba, D. Fernando de Mesa, y de la sacristía de la propia catedral de Burgos: "Sentencias de don Ferrando, obispo de Córdoua, vn ordinario e vn psalterio glosado de la sacristanía de Burgos» (vid. Pereda, F. J., Catedral de Burgos, n. 126, págs. 174-179). 
y del arcediano de la ciudad Pedro Pascual ${ }^{53}$, demuestran su elevada formación y vinculación al mundo de la cultura de su época, y no sólo religiosa. La diócesis de Burgos contaba, por consiguiente, con recursos humanos perfectamente capacitados para ello y el ejercicio de sus funciones y obligaciones asi lo requería.

\section{LOS DOCUMENTOS DEL CABILDO CATEDRALICIO DE BURGOS}

En los 46 documentos conservados de esta época - sólo 12 originales- protagonizados por el cabildo catedralicio de Burgos, bien como institución, bien por algunos de sus componentes, detectamos dos realidades muy distintas.

Hasta 1220 , los documentos presentan, generalmente, el nombre del autor material, es decir, son suscritos; su contenido va referido, sobre todo, a permutas y prestimonios; la expresión de la fecha ha utilizado siempre el sistema de la era hispánica para el cómputo de los años. En suma, no se diferencian apenas nada de lo que sería la producción documental de cualquier particular.

A partir de dicha fecha, más concretamente desde 1222, empiezan a generalizarse los documentos sin suscripción de autor material, ya que el principal y casi único sistema de validación empleado va a ser el sello. Esto coincide, asimismo, con el sistema del anno Domini para la expresión del año y con la inclusión del anuncio de validación. Su contenido, sin faltar algunos similares a los anteriores, se diversifica, pero sobre todo se especializa en cuestiones tocantes exclusivamente a una institución religiosa, en las que se podrían citar controversias entre diferentes monasterios, citaciones a prelados o acuerdos capitulares. Muestran peculiares formas de expresión y de emisión, pues ya son producto de una oficina propia de expedición documental.

53 Prolija es la relación de libros, fundamentalmente de Derecho, que señala el magister Petrus Pascasii, arcediano de Burgos, en su testamento de 3 de marzo de 1277, reflejo, como es Iogico, de su actividad judicial. Además de una Biblia propia y de la devolución de unos Evangelios a la sacristia de la catedral, menciona los siguientes de su propiedad: "Decretos, Decretales Nueuas, las Glosas de sus Decretos, las Causas, el Esforçado, Summa de Galfredo, Libello de Rofredo, un Código, Libro de los Fueros que hizo el rey, un Digesto Vieio, la Instituta, la Summa de Aço, el Libro de Salomón, Libro de los Sermones, Libro de las Sentencias, Libros de las Horas" (vid. Pereda, F. J., Catedral de Burgos, n. 142, págs. 200-204). Por el contrario, Gutier Pérez de la Vega, arcediano de Valpuesta, sólo menciona un libro del Fuero y dos libros mayores en su testamento de 1295 (Ibidem, n. 307, págs. 19-21). 
Con alguna excepción en las últimas décadas de este siglo, el «pergamino" sigue siendo la principal materia escritoria utilizada, adecuadamente preparado para recibir la escritura y, por lo general, pautado. Cuando han sido confeccionados varios originales múltiples y ha sido empleado el tradicional sistema de letras partidas por $A B C$, se solían dibujar todas las letras del abecedario que cupiesen, en función de la longitud del pergamino, en módulo más bien grande, y éste se cortaba en ángulo, de manera dentada, más que recto ${ }^{54}$.

La "escritura" que muestran se integra, como es lógico, en el ciclo de las góticas castellano-leonesas, en esa primera gótica cursiva que era empleada tanto en el ámbito real como en el notarial, más evolucionada al final de la centuria y al principio más caligráfica y cercana a esa carolina tardía introducida en estos reinos. A veces, llama la atención su módulo, más bien grande, coincidente con un tratamiento más cuidado y regular, con una amplia separación de renglones o, por decirlo de otra manera, con una unidad de pautado mayor a la habitual en el mundo documental. En ocasiones, el modelo que presentan algunos recuerda inmediatamente al ámbito real ${ }^{55}$, pero no el pontificio, en otros a la producción notarial coetánea. La impresión global que se obtiene de un rápido análisis de los pocos documentos originales conservados es la de estar ante unos productos escritos que han sido elaborados con cuidado y esmero.

Otro aspecto destacable en esta documentación es el predominio del "latín" con respecto al castellano, ya que éste, constatado por primera vez en 1262 , es utilizado tan sólo en siete documentos ${ }^{56}$, aunque no viene

${ }_{54}$ El empleo de este sistema de letras partidas se muestra mucho más utilizado en la documentación protagonizada por el obispo de la diócesis, que por su cabildo, fundamentalmente en ese conjunto de sentencias y actuaciones de índole judicial que se conservan del episcopado de $D$. Mauricio. No sólo su frecuente uso resulta llamativo, sino también el número de ejemplares que de un mismo asunto se llegaban a confeccionar, y que, gracias a la costumbre impuesta de señalarlo en los anuncios de validación, nos dan idea de la creciente actividad escrituraria a la que estaba sometida esa oficina encargada de elaborar los documentos de los prelados burgaleses: «Facte sunt due carte tenoris eiusdem per alphabetum diuise... quarum una retinebit burgensis ecclesia, altera, uero, seruabit uniuersitas sepe dicta” (GarRido, J. M., Catedral de Burgos, n. 511, págs. 331-334); "vt autem factum istud certiori fide roboretur, quatuor cartas inde fecimus sigillis nostris et capitulorum nostrorum roboratas, ita quod una reseruetur in monasterio Regali burgensi, secunda apud monasterium Sancti Emiliani, alie due remaneant penes episcopos memoratos" (SERRANO, L., $D$. Mauricio, n. 12, págs. 142-143. LizoAIN, J. M., Las Huelgas, n. 237, págs. 343-345).

55 Garrido, J. M., Catedral de Burgos, n. 537, págs. 370-371. Vivancos, M., Silos, n. 102, págs. 156-157.

56 Serrano, L., Covarrubias, n. 77, págs. 120-121. Pereda, F. J., Catedral de Burgos, n. 60 , págs. $82-85$; n. 83 , págs. $119-123$; n. 263 , págs. $325-329 ;$ n. 278 , págs. $349-350 ;$ n. 392 , págs. 177-185; n. 313, págs. 36-38. 
determinado su uso por la cualidad del contenido, ya que, por ejemplo, los acuerdos capitulares de 1291 fueron redactados en castellano. Como es normal en la paulatina imposición de esta lengua romance, equiparable a lo acontecido en la cancillería real, hay documentos que presentan sus fórmulas iniciales y finales en latín y el resto en castellano ${ }^{57}$. Una evolución similar se observa en los documentos protagonizados por los obispos de Burgos, pero se puede señalar que en éstos el castellano hizo su aparición antes - a partir de 1227-y se impuso desde 1244, pero sobre todo que se empleó con mayor asiduidad para todo tipo de negocios y asuntos, aunque fueran estrictamente eclesiásticos. Se observa, por consiguiente, que la escribania capitular prefirió más la lengua latina para la redacción de sus documentos que la episcopal.

Doble forma de redacción se puede constatar. Del conjunto, nueve documentos presentan una redacción objetiva, uno es una misiva y el resto ha sido redactado de forma subjetiva. Sin embargo, el hecho de utilizar una $u$ otra no viene condicionado por el contenido, pues encontramos que idénticos asuntos han sido recogidos en ambas formas - permutas, prestimonios y compromisos--, con la excepción de las confirmaciones de prior por parte del cabildo burgalés, que, ante la circunstancia de hallarse la sede vacante por el fallecimiento de fray Fernando a fines de siglo, ejerce estas funciones privativas de su titular ${ }^{58}$.

Entre los documentos que no son producto de esta escribanía capitular, una «invocación» verbal al nombre de Dios es el modo habitual de iniciar su tenor diplomático ${ }^{59}$, mientras que, después, esta fórmula protocolaria es reservada para contenidos muy determinados: una avenencia ${ }^{60}$ y dos confirmaciones capitulares de cargos monacales ${ }^{61}$. Las tres cerradas con una adprecación. Justo a principio de siglo y continuando con la tradición anterior, es invocado el nombre de Cristo ${ }^{62}$ y el misterio de la Trinidad ${ }^{63}$.

\footnotetext{
57 Garrido, J. M., Catedral de Burgos, n. 509, págs. 330-331. Pereda F. J., Catedral de Burgos, n. 342, págs. 75-76.

se Pereda, F. J., Catedral de Burgos, n. 340, págs. 70-72; n. 344, págs. 78-79. Lo mismo se observa en otras confirmaciones de prior y abad intitulados por el obispo de Burgos.

59 Garrido, J. M., Catedral de Burgos, n. 379, págs. 173-174; n. 389, págs. 182-183; n. 391 , págs. $185-186$; n. 392, pág. 187; n. 400, págs. 195-196; n. 411, págs. 207-208; n. 412, págs. 208209 ; n. 413 , págs. $209-210$; n. 422, págs. 220-221; n. 430, págs. 234-235; n. 482, págs. 297-298; $n$. 486, págs. $301-302 ;$ n. 493 , págs. $311-312$; n. 495, págs, $313-314$; n. 498 , pág. 317 ; n. 500, págs 319-320; n. 508, pág. 329 ; n. 509, págs. 330-331; n. 513, págs. 335-336; n. 545, págs. 385-386.

60 Pereda, F. J., Catedral de Burgos, n. 83, págs. 119-123.

61 Ibidem, n. 340 , págs. 70-72; n. 344, págs. 78-79.

62 Serrano, L., Obispado de Burgos, n. 240, págs. 363-364. Garrido, J. M., Catedral de Burgos, n. 348, pág. 138; n. 410, págs. 206-207.

63 Serrano, L., Obispado de Burgos, n. 238, págs. 360-362.
} 
Ausente el preámbulo ${ }^{64}$ en todos ellos, la «notificación» es casi constante, bien a continuación de la fórmula anterior, bien como inicio de los documentos. La forma utilizada en los documentos no cancillerescos es «notum sit omnibus hominibus tam presentibus quam futuris» ${ }^{65}$. Pero en los otros, además de ésta, son empleadas otras que también se detectan en la documentación protagonizada por el titular de la sede: «Notum sit omnibus ad quos peruenerint hec scriptura» ${ }^{66} \mathrm{y}$ "nouerint uniuersi presentem litteram inspecturis» ${ }^{67}$. La forma en castellano se introduce en una cronología similar, aunque algo posterior, a la del obispo y en su doble modalidad: Connosçuda cosa sea ${ }^{68}$ a partir de 1262 y sepan quantos esta carta vieren

${ }_{54}$ En la documentación episcopal del siglo xil1, el preámbulo está escasamente representado y su uso no siempre va condicionado por la mayor solemnidad de su contenido, ya que asuntos tan importantes para una institución religiosa como son las constituciones o estatutos capitulares carecen de una justificación general previa a su desarrollo. De las cuatro existentes, las dos primeras llevan preámbulo (Serrano, L., D. Mauricio, págs. 143-147. Pereda F. J., Catedral de Burgos, n. 65, págs. 91-92), y las otras dos no (/bidem, n. 262, págs. 322-325; $n$. 317, págs. 42-44). Dos sentencias judiciales (Serrano, L., D. Mauricio, n. 8, págs. 136-139. Rooriguez de LAMA, I., La Rioja, III, n. 490, págs. 274-278), dos avenencias (Ibidem, n. 12, págs. 42-43. MansiLla, D., Catálogo Burgos, n. 580, págs. 151-152) y un compromiso (GARRIDO, J. M., Catedral de Burgos, n. 543, págs. 382-383) también lo tienen. Entre ellos, destacan los de carácter diplomático que inciden, como se sabe, en la firmeza de lo escrito como cautela para impedir el olvido de los hechos establecidos y evitar futuras dudas. Desarrollo singular presenta el preámbulo de la Constitución mauriciana de 1230 , de contenido religioso, con citas sagradas y eruditas referidas a los dones del Espiritu Santo, a la necesidad de establecer un orden - «sine ordine mundi sensibilis machina non subsisteret etiam per momentum»- y una jerarquia, a tenor de las enseñanzas de Dionisio y de la realidad celestial (SERRANo, L., D. Mauricio, n. 13, págs. 143-147). Un preámbulo, por consiguiente, que refleja la directriz de este famoso obispo burgalés, empeñado en hacer cumplir las disposiciones del IV Concilio de Letrán y los intereses del Papa. También de carácter religioso y con citas neotestamentarias es el que sirve de pórtico a un estatuto capitular promulgado por D. Martín en 1264 (PEAEDA, F. J., Catedral de Burgos, n. 65, págs. 91-92), similar al utilizado por el obispo de Bolonia en 1255 y 1267 para favorecer las limosnas de los feligreses a monasterios (vid. CENCETTI, G., "Note de diplomatica vescobile bolognese dei secoli XI-XIII», en Scritti di Paleografia e Diplomatica in onore di $V$. Federici (Florencia 1945), pág. 19).

6.5 Serrano, L., Obispado de Burgos, n. 238, págs. 360-362; n. 240, págs. 363-364; n. 241 , págs. 364-365. GarRido, J. M., Catedral de Burgos, n. 400, págs. 195-196; n. 410, págs. 206207 ; n. 411, págs. 207-208; n. 412, págs. 208-209; n. 422, págs. 220-221; n. 430, págs. 234$235 ;$ n. 471 , págs. $284-285$; n. 482, págs. 297-298; n. 486, págs. 301-302; n. 493, págs. $311-$ 312 ; n. 495 , págs. $313-314$; n. 498 , pág. 317 ; n. 500 , págs. $319-320 ;$ n. 508 , pág. $329 ;$ n. 513 , págs. $335-336 ;$ n. 523 , págs. $351-352 ;$ n. 536 , pág. $369 ;$ n. 537 , págs. $370-371$; n. 545 , págs. 385-386. Pereda, F. J., Catedral de Burgos, n. 102, págs. 156-157. Vivancos, M., Silos, n. 340 , págs. $70-72$.

66 López de Silanes, C., Calceatense, n. 33, págs. 32-33. Pereda, F. J., Catedral de Burgos, n. 99, págs. 141-142.

${ }_{67}$ Pereda, F. J., Catedral de Burgos, n. 44, págs. 64-65; n. 98, págs. 140-141; n. 186, págs. 253-254. Una variante de esta forma es noverint universi presens publicum instrumentum inspecturis, también presente en algún documento boloñés de la segunda mitad del siglo XIII (vid. Cencetti, G., op. cit., pág. 32).

${ }_{68}$ Pereda, F. J., Catedral de Burgos, n. 60, págs. 82-85; n. 83, págs. 119-123. 
en $1291^{69}$. Los documentos de carácter administrativo o epistolar hacen uso de una forma más directa y personal: noveritis ${ }^{70}$, bien sabedes ${ }^{71}$ y sepades ${ }^{72}$, a excepción de la comunicación dirigida por el cabildo a todos los arzobispos y obispos, que adopta una expresión de mayor respeto y solemnidad: Paternitati uestre notum facimus per presentes ${ }^{73}$ y precedida, como es lógico, de la fórmula de beso de manos: mannum oscula cum reuerencia tam debita quam deuota. Precisamente, estas últimas formas se relacionan con la diferenciación de la dirección como fórmula diplomática y con la "salutación", que presenta un desarrollo diferente a la de los documentos de los obispos ${ }^{74}$ : Salutem et semper Domini gratiam promereri es la utilizada por el deán de Burgos para dirigirse al obispo de Segovia ${ }^{75}$, salutem in Domino en un mandato al prior y monasterio de S. Pedro de Cardeña ${ }^{76}$ y simplemiente salut el vicario general para amonestar al tesorero de la colegiata de Covarrubias ${ }^{77}$.

El cabildo como institución o algunos de sus componentes en particular justifican las posibles variantes constatadas en la «intitulación». El deán, principal dignidad del mismo, intitula en solitario una prórroga para una decisión judicial ${ }^{78}$ y una citación ${ }^{79}$; junto con los tres mayordomos es el otorgante de gran parte de las permutas ${ }^{80} \mathrm{y}$ los prestimonios ${ }^{81}$ de los primeros años, pero también de un censo ${ }^{82}$, una donación ${ }^{83}$ y las dotaciones

\footnotetext{
Ibidem, n. 263 , págs. $325-329$; n. 313 , págs. 36-38.

Ubieto, A., Cuéllar, n. 17, págs. 47-48.

Serrano, L., Covarrubias, n. 77, págs. 120-121.

PeReda, F. J., Catedral de Burgos, n. 342, págs. 75-76.

Ibidem, n. 346, págs. 80-81

Atendiendo a las normas del Ars Dictandi, la fórmula de la salutación en los documentos
} episcopales va a adoptar un desarrollo distinto en función de la persona o institución a quien vaya dirigida. Asi, en una comunicación con el obispo de Zamora, ésta denota cierta cercanía y amistad - "salutem et sincere dilectionem affectum" (MARTín MARTín, J. L., Documentos zamoranos: del Archivo catedralicio de Zamora (1128-1261). Salamanca 1982, n. 108, pág. 83)-; cuando se dirige al deán y cabildo de Calahorra, se puede apreciar el magisterio espiritual de su otorgante en un mandato de 1237, similar a las utilizadas por otros prelados — «salutem et sinceram in Domino caritatem»- (RodrigueZ de Lama I., La Rioja, IV, n. 120, pág. 115); y, finalmente, la más común es la sencilla "salutem et benedictionem" (OCEJA, I., Oña, n. 171 y 182, págs. 149 y 156) en latín o "salut $e$ bendiçión" en castellano (Ibidem, n. 213, págs. 210-211; n. 388 y 392, págs. 174 y 178).

Ubieto, A., Cuéllar, n. 17, págs. 47-48.

Pereda, F. J., Catedral de Burgos, n. 342, págs. 75-76.

Serrano, L., Covarrubias, n. 77, págs. 120-121.

Álamo J., Oña, n. 502, págs. 615-617.

UBieto, A., Cuéllar, n. 17, págs. 47-48.

80 GarRido, J. M., Catedral de Burgos, n. 400, págs. 195-196; n. 493, págs. 311-312; n. 498, pág. $317 ;$ n. 500 , págs. $319-320 ;$ n. 513 , págs. 335-336.

*1 Ibidem, n. 412, págs. 208-209; n. 482, págs. 297-298; n. 495, págs. 313-314.

82 Serrano, L., Obispado de Burgos, n. 240, págs. 363-364. Garrido, J. M., Catedral de Burgos, n. 410, págs. 206-207.

8.3 Garaido, J. M., Catedral de Burgos, n. 523, págs. 351-352. 
de capellanías ${ }^{84}$; con dos arcedianos de la diócesis certifica el traslado de una serie de documentos ${ }^{85}$; y con el cabildo da varios prestimonios ${ }^{86}$, una permuta ${ }^{87}$, una comunicación de carácter general ${ }^{88}$, un mandato ${ }^{89}$, varios acuerdos capitulares ${ }^{90}$, la confirmación de elección de abad de un monasterio ${ }^{91}$ y la aprobación y promesa de cumplir las constituciones dadas a la catedral de Burgos: «Ego domnus Benedictus, decanus ecclesie Sancte Marie burgensis, una cum conuentu eiusdem ecclesie ${ }^{92}$; Ego domnus Benedictus, decanus ecclesie Sancte Marie, una cum mayordomos ecclesie, scilicet, lohannes Peregrin et Martinus Cardenna et domno Vitale, et cum omni conuentu eiusdem ecclesie" ${ }^{93}$.

Los mayordomos protagonizan en solitario otras dos permutas ${ }^{94} \mathrm{y}$ el acta de entrega de bienes ${ }^{95}$ : “Nos mayordomos, qui somos presentes in ecclesia Sancte Marie burgensis, scilicet, ego domnus lohannes, scriuano, et ego domnus Petrus Ferrandi et ego domnus magister Rodericus et cum mandamiento de todo el capítulo" ${ }^{96}$. A su vez, varios arcedianos son los otorgantes de una sentencia arbitral ${ }^{97}$ y de otra dotación de capellanía ${ }^{98}$. Junto con el sacristán y uno de los abades pertenecientes al cabildo, un arcediano es nombrado árbitro en una carta de compromiso ${ }^{99}$. Siendo juez del obispo, el canónigo Domingo González es el responsable de una sentencia ${ }^{100}$ y Martín Ruiz, como vicario general, de una amonestación ${ }^{10}$. Por último, el cabildo, sin mencionar ninguna de sus dignidades o componentes, es el protagonista de permutas ${ }^{102}$, de un prestimonio ${ }^{103}$, de una

${ }_{84}$ Ibidem, n. 389 , págs. $182-183 ;$ n. 545 , págs. 385-386.

85 Pereda, F. J., Catedral de Burgos, n. 99, págs. 141-142.

86 Garrido, J. M., Catedral de Burgos, n. 379, págs. 173-174; n. 421, pág. 219.

u7 Ibidem, n. 471, págs. 284-285.

8z Pereda, F. J., Catedral de Burgos, n. 346, págs. 80-81.

as Ibidem, n. 342, págs. 75-76.

90 Ibidem, n. 60, págs. 82-85.

91 lbidem, n. 344, págs. 78-79.

92 Garfido, J. M., Catedral de Burgos, n. 379, págs. 173-174.

43 Ibidem, n. 389, pág. 183.

94 Garrido, J. M., Catedral de Burgos, n. 486, págs. 301-302; n. 508, pág. 329.

95 Pereda, F. J., Catedral de Burgos, n. 278, págs. 349-350.

96. Garrido, J. M., Catedral de Burgos, n. 486, págs. 301-302.

9. Garrido, J. M., Catedral de Burgos, n. 537, págs. 370-371. Vivancos, M., Silos, n. 102, págs. $156-157$.

98 Serrano, L., Obispado de Burgos, n. 238, págs. 360-362.

99 Pereda, F. J., Catedral de Burgos, n. 44, págs. 64-65.

Ion Ibidem, n. 392, págs. 177-185.

101 Serrano, L., Covarrubias, n. 77, págs. 120-121

102 Garrido, J. M., Catedral de Burgos, n. 348, pág. 138; n. 422, págs. 220-221.

103 Serrano, L., Obispado de Burgos, n. 241, págs. 364-365. Garaido. J. M., Catedral de Burgos, n. 430 , págs. $234-235$. 
venta ${ }^{104} \mathrm{y}$, de igual manera, de un ordenamiento ${ }^{105}$, una carta de compromiso ${ }^{106}$ y de otra confirmación de elección de prior de un monasterio ${ }^{107}$ : El cabildo de Sancta María de Burgos ${ }^{108}$.

"Dirección" individualizada sólo se encuentra en los cuatro documentos, anteriormente citados, que llevan salutación, pues suele ir englobada dentro de la disposición, tras el verbo dispositivo. En función de la mayor o menor dignidad del destinatario, ésta ocupa el primer o segundo puesto en la secuencia formulística de este tipo de documentos. Es la primera en la citación al obispo de Segovia ${ }^{109}$ y en la comunicación a las autoridades eclesiásticas ${ }^{110}$; la segunda, en la amonestación al tesorero de Covarrubias y en el mandato dirigido al monasterio de S. Pedro de Cardeña.

Generalmente, la necesidad de justificar o exponer las causas motivadoras de una acción ha sido poco utilizada. Casi todas las permutas, las dos ventas y otros contenidos similares llevan la típica "exposición» de espontaneidad; una dotación de capellanía, la búsqueda del remedio por los pecados cometidos a lo largo de la vida. El resto de las justificaciones concretas están directamente relacionadas con la disposición. Así, en compromisos, sentencias $u$ amonestación es detallado el origen de la controversia o discordia y son expuestos los pasos seguidos antes de la deliberación " $"$ ". En muchos casos van asegurados con la inserción de determinados documentos que refuerzan o contemplan el proceso llevado a cabo.

Respecto a los verbos empleados para caracterizar la "disposición", la combinación de dare y concedere resulta ser lo más habitual en la primera mitad de siglo; se puede observar con posterioridad una mayor precisión de términos $y$, asimismo, más variedad de contenidos:

- facio cambium ${ }^{112}$.

Pereda, F. J., Catedral de Burgos, n. 60, págs. 82-85.

Ibidem, n. 99, págs. 141-142.

Ibidem, n. 313 , págs. 36-38.

Ibidem, n. 340 , págs. 70-72.

Peña, J., San Juan, n. 88, págs. 129-131.

Reverendo patri suo in Christo et domno... (UBIETO, A., Cuellar, n. 17, págs. 47-48).

Universis archiepiscopis et episcopis ad quos presentes littere pervenerint (PEREDA, F. J., Catedral de Burgos, n. 346, págs. 80-81).

"1 En los documentos episcopales son muy habituales, de igual modo, las exposiciones que detallan los conflictos o controversias existentes; en ocasiones, se refleja la petición o ruego de los interesados. Pero, sobre todo, la consulta, asesoramiento y consenso del cabildo a la hora de una deliberación de indole procesal, poniendo de manifiesto el deseo del obispo de lograr la paz entre los litigantes.

11. GarfiDo, J. M., Catedral de Burgos, n. 391, págs. 185-186; n. 392, pág. 187; n. 400, págs. 195-196; n. 413, págs. 200-210; n. 422, págs. 220-221; n. 471, pág. 284-285; n. 486, págs. 301- 
- damus / damus et concedimus... pro tali pacto ${ }^{113}$

- damus a fondos ${ }^{114}$

- damos ${ }^{115}$

- damus et concedimus... sub tali conditione / damus et concedimus... pro uestro aniuerssario / dono et concedo... cantent missas ${ }^{116}$

- cognosco et otorgo ${ }^{117}$

- vendo et robro / vendemos ${ }^{118}$

- condempnamus ${ }^{19}$

- absoluimus et absolutum denunciamus ${ }^{120}$

- statuimus et communiter ordinamus ${ }^{121}$

- aprobarunt... promiserunt ${ }^{122}$

- prorrogaui terminum ${ }^{123}$

- inspeximus ${ }^{124}$

- moneo... cito $^{125}$

- amonesto ${ }^{126}$

- mandamos ${ }^{127}$

También en las «cláusulas finales» se observa esa diferenciación apuntada al principio de este apartado. Los primeros vienen caracterizados por la presencia de cláusulas de sanción espiritual -ira divina- ${ }^{128}$ y

302; n. 493, págs. 311-312; n. 498, pág. 317; n. 500, págs. 319-320; n. 508, pág. 329; n. 513 , págs. 335-336.

${ }_{113}$ Serrano, L., Obispado de Burgos, n. 240, págs. 363-364; n. 241, págs. 364-365. GarRido, J. M., Catedral de Burgos, n. 379, págs. 173-174; n. 410, págs. 206-207; n. 412, págs. 208-209; n. 421, pág. 219; n. 430, págs. 234-235; n. 482, págs. 297-298; n. 495, págs. 313-314.

113 Garaido, J. M., Catedral de Burgos, n. 523, págs. 351-352.

15 Pereda, F. J., Catedral de Burgos, n. 313, págs. 36-38.

16 Serrano, L., Obispado de Burgos, n. 238, págs. 360-362. Garrido, J. M., Catedral de Burgos, n. 389 , págs. $182-183 ;$ n. 545 , págs. 385-386.

117 Garnido, J. M., Catedral de Burgos, n. 411, págs. 207-208.

118 Ibidem, n. 509, págs. 330-331.

119 Ibidem. n. 537, págs. 370-371. Vivancos, M., Silos, n. 102, págs. 156-157.

120 Pereda, F. J., Catedral de Burgos, n. 186, págs. 253-254.

121 ibidem, n. 99, págs. 141-142.

122 Pereda, F. J., Catedral de Burgos, n. 98, págs. 140-141.

123 Álamo, J. del, Oña, n. 502, págs. 615-616.

124 LOPEZ DE SILANES, C., Colección diplomática calceatense: Archivo catedral (1125-1397), Logroño, 1985, n. 33, págs. 32-33.

125 Ubieto, A., Cuéllar, n. 17, págs. 47-48.

126 Serrano, L., Covarrubias, n. 77, págs. 120-121.

127 Pereda, F. J., Catedral de Burgos, n. 342, págs. 75-76.

${ }_{128}$ Garrido, J. M., Catedral de Burgos, n. 391, págs. 185-186; n. 392, pág. 187, n. 400, págs. 195-196; n. 413, págs. 209-210; n. 471, págs. 284-285; n. 493, págs. 311-312; n. 500, págs. 319 320 ; n. 508, pág. 329 ; n. 509, págs. $330-331$; n. 513, págs. 335-336. 
pecuniaria, de ciertas cantidades y mejora del daño causado ${ }^{129}$. Muestran la misma realidad que la documentación episcopal coetánea, en la que tampoco es destacable el uso de esta cláusula sancionadora en este siglo, al contrario de lo que ocurría en épocas anteriores ${ }^{130}$.

Los segundos, se diferencian por la costumbre de incluir de manera constante el anuncio de validación. Esta fórmula, de desigual desarrollo, presenta una diferente redacción, pero no constatamos aqui el que caracterizaba los documentos de los obispos, ni el anuncio de que hubieran sido confeccionados varios originales ${ }^{131}$. Sólo en una certificación de traslado, nos topamos con uno exactamente igual: "In cuius rey testimonium eorum transcriptum sigillis nostri fecimus consignari» ${ }^{132}$. En unos, se alude expresamente al valor del sello como medio de garantia y de evitar a posteriori cualquier duda que pudiera suscitarse: «Et ne aliquis de hoc valeat dubitare, presenti carte sigillum nostrum duximus apponendum» 133; "et ut de ista consuetudine in posterum nullan dubietas oriatur, sigillum comune nostri capituli apposuimus huic carte» ${ }^{134}$; y en castellano, «e porque esto sea firme e non venga en dubda, fiçiemos seellar esta carta con nuestro seello" ${ }^{135}$. En otros, el anuncio de validación mediante el sello del cabildo va acompañado del ruego al obispo de Burgos para que confirme y ponga su sello en una venta y en una avenencia, así como al alcalde de la ciudad para que haga poner el sello del concejo en la primera.

129 loidem.

130 Uno de los estatutos capitulares intitulados por el obispo de la diócesis se escapa a la norma y presenta una sanción espiritual singular y especial: "Los que contra esto pasaren por ese mismo fecho cayan en sentençia de descomunión e sean denunçiados con las maldiçiones que son escriptas en la ley, e que sean esquiuados e malditos por rebelles e desobedientes a Sancta Eglesia, canpanas tannidas e candelas amatadas, en la nuestra eglesia cathedral e por todo nuestro obispado; e los logares donde to tomaren e do lo leuaren que por ese mismo fecho sean interdictos; e si los que este robo tomaren o mandaren tomar o fueren en conseio, si murieren, que non sean enterrados fasta que fagan cumplidamiente emienda e sean absueltos" (PEREDA, F. J., Catedral de Burgos, n. 317, págs. 42-44).

${ }_{131}$ Teniendo en cuenta esta ausencia y que de muchos no se ha conservado el original, cartas partidas por ABC son tan sólo cuatro (SERRANO, L., Obispado de Burgos, n. 238, págs. 360362. Garkido, J. M., Catedral de Burgos, n. 536, pág. 369; n. 537, págs. 370-371. Vivancos, M., Silos, n. 102, págs. 156-157). En una avenencia, el escribano público de Burgos, Lucas González, señala que confeccionó dos cartas partidas por ABC (PEREDA F. J., Catedral de Burgos, n. 83, págs. 119-123).

${ }_{132}$ LOPEZ DE SILANES, C., Calceatense, n. 33, págs. 32-33. Dos variantes de esta forma podemos detectar: "In quorum testimonium nos, predicti arbitri, a partibus rogati fecimus presentem paginam sigillorum nostrorum munimine roborari" (PEREDA, F. J., Catedral de Burgos, n. 44, págs, 64 $65)$. "In cuius rey testimonium presens carta sigillis decani et capituli fuit unanimiter roborata" (lbidem, n. 98, págs. 140-141).

133 Pereda, F. J., Catedral de Burgos, n. 99, págs. 141-142.

${ }^{134}$ lbidem, n. 346 , págs. 80-81

${ }_{135}$ Ibidem, n. 313, págs. 36-38. 
En los acuerdos capitulares de 1291, esta cláusula corroborativa es completada con el anuncio de la suscripción autógrafa de cada uno de los integrantes del cabildo y con la aposición de los sellos personales de cada uno: "E por mayor firmedumbre scribimos cada vno de nos nuestros nombres en esta carta con nuestras manos e pusiemos en ella nuestros seellos, cada vno de nos del que vsamos en testimonio de verdat" ${ }^{136}$. Estas suscripciones, dispuestas en cuatro columnas de desigual número, suman 51 nombres y observan la prelación establecida en orden a su importancia, lo que confiere una mayor solemnidad, desgraciadamente no se ha conservado el original.

La representación de otras cláusulas finales es realmente anecdótica, además de las ya mencionadas, podemos indicar que ciertas permutas acompañan la sanción con una breve corroboración: «Hoc nostrum cambium remaneat firmum usque in perpetuum" ${ }^{137}$. En 1281 y en una amonestación del vicario de Burgos al tesorero de Covarrubias es añadida una conminatoria general: "E non querades al fazer» ${ }^{130}$ y otra de devolución: "la carta leyda, dalla al que la lieva" ${ }^{139}$. Esta última fue utilizada, también, por el deán de la catedral a la hora de citar al obispo de Segovia en 1257: "reditte litteras portatori et nobis satisfaciat de translato" ${ }^{140}$. Del mismo modo, los documentos episcopales incorporaron, a fines de esta centuria, una y otra como refuerzo de unos mandatos, en consonancia con lo que ocurría en los documentos de la cancillería real. Finalmente, un compromiso es asegurado con una de promesa de cumplimiento y de obligación de bienes ${ }^{141}$.

Nuevamente detectamos en la expresión de la "data» diferencias entre el grupo de documentos que consideramos extracancillerescos, del que es producto de esa oficina de expedición capitular. En primer lugar, el incipit utilizado, ya que mientras entre los primeros resulta ser invariable el facta carta ${ }^{142}$,

\footnotetext{
136 Ibidem, n. 263, págs. 325-329

${ }^{37}$ Garrido, J. M., Catedral de Burgos, n. 471, págs. 284-285; n. 493, págs. 311-312; n. 500, págs. $319-320 ;$ n. 508, pág. 329; n. 513, págs. 335-336.

138 Serrano, L., Covarrubias, n. 77, págs. 120-121.

139 Ibidem

140 Ubieto, A., Cuéllar, n. 17, págs. 47-48.

141 Pereda, F. J., Catedral de Burgos, n. 313, págs. 36-38.

142 Serrano, L., Obispado de Burgos, n. 240, págs. 363-364; n. 241, págs. 364-365. Garrido, J. M., Catedral de Burgos, n. 379, págs. 173-174; n. 389, págs. 182-183; n. 391, págs. 185-186; n. 392, pág. 187; n. 400, págs. 195-196; n. 410, págs. 206-207; n. 411, págs. 207-208; n. 412, págs. 208-209; n. 413, págs. 209-210; n. 421, págs. 219 ; n. 422, págs. 220-221; n. 430, págs. 234-235; n. 471, págs. 284-285; n. 482, págs. 297-298; n. 486, págs. 301-302; n. 493, págs. 311-312; n. 495, págs. $313-314 ;$ n. 498 , pág. $317 ;$ n. 500 , págs. $319-320 ;$ n. 508 , pág. 329 ; n. 509, págs. $330-$ 331 ; n. 513 , págs. $335-336$; n. 523, págs. 351-352; n. 545, págs. 385-386. La única excepción es bastante similar: «Factum est cambium» (Ibidem, n. 384, pág. 138).
} 
en los segundos hay una mayor variedad y son más acordes con los empleados por los titulares de la diócesis. Actum suele ser el inicio preferido con diferentes variantes ${ }^{143} \mathrm{y}$ en su defecto datum o su traducción dada ${ }^{144}$. En ciertos casos, una frase amplia en castellano combina ambos participios: «Fecho fue esto y dada esta carta" o "todo esto fue fecho e cumplido" ${ }^{145}$. No se incluye nunca ningún tipo de calificación o precisión jurídica ni diplomática.

En segundo lugar, la ausencia de día y de elemento tópico. Resulta una característica de los primeros el hecho de que en la expresión de la fecha sólo aporten el dato del mes y año. En los segundos, sin embargo, no suele faltar el día y para ello, cuando el texto está en latín, hacen uso del sistema de calendación romana ${ }^{146} y$ en ocasiones incluyen el día de la semana ${ }^{147}$. Por otra parte, a partir de 1245 es habitual señalar el lugar de expedición, siempre Burgos, y, como ocurría en los documentos de los obispos ${ }^{148}$, se concreta un poco más y se añade que ello aconteció mientras estaban en cabildo general, cuya reunión tenía lugar dentro de la catedral, en la capilla de S. Pablo ${ }^{149}$. La tradicional fórmula del regnante es

143 Actum (Garrido, J. M., Catedral de Burgos, n. 537, págs. 370-371. Vivancos, M., Silos, $\mathrm{n}$. 102, págs. 156-157. Pereda, F. J., Catedral de Burgos, n. 99, págs. 141-142). Actum est hoc (Pereda F. J., Catedral de Burgos, n. 98, págs. 140-141; n. 186, págs. 253-254; n. 340, págs. 7072; n. 344, págs. 778-79). Acta sunt hec (Álamo, J. del, Oña, n. 502, págs, 615-617).

144 Datum (López de Silanes A., Calceatense, n. 33, págs. 32-33. Úbieto, A., Cuéllar, n. 17, págs. 47-48. Pereda, F. J., Catedral de Burgos, n. 346, págs. 80-81). Dada (Serrano, L., Covarrubias, n. 77 , págs. 120-121. Pereda, F. J., Catedral de Burgos, n. 313, págs. 36-38; n. 342, págs. 75-76).

145 Pereda, F. J., Catedral de Burgos, n. 263, págs. 325-329; n. 83, págs. 119-123.

146 Garrido, J. M., Catedral de Burgos, n. 537, págs. 370-371. Vivancos M., Silos, n. 102, págs. 156-157. LoPEZ de Sllanes, C., Caceatense, n. 33, págs. 32-33. Ubieto, A., Cuéllar, n. 17, pàgs. 47-48. Pereda, F. J., Catedral de Burgos, n. 44, págs. 64-65; n. 98, págs. 140-141; n. 99, págs. $141-142$; n. 186 , págs. $253-254$; n. 340 , págs. $70-72 ; n$. 344 , págs. $78-79$. En los documentos episcopales también se utilizaba la calendación romana para los redactados en latín, pero en castellano se hacia uso del sistema directo y, en algunos, del de dias andados y por andar.

${ }_{147}$ Pereda, F. J., Catedral de Burgos, n. 44, págs. 64-65; n. 60, págs. 82-85; n. 83, págs. 119$123 ;$ n. 278, págs. 349-350; n. 392, págs. 177-185.

${ }_{148}$ En esta centuria, la data tópica se incorpora a los elementos aportados en los documentos episcopales. Evidentemente Burgos es el lugar que se repite una y otra vez, alternando, en ocasiones, con el de Quintanadueñas. En el episcopado de D. Mauricio se instaura la costumbre de indicar que el hecho reflejado tuvo lugar «in palacio episcopi», referido al de Burgos, pero también al de Quintanadueñas. En 1243, siendo obispo D. Juan, se añade que el palacio episcopal estaba junto a Santa Cruz. La llamada capilla del obispo, dentro de la catedral, fue el lugar donde fue confirmada una venta.

148 "In capitulo burgensi" (GaRRIDO, J. M., Catedral de Burgos, n. 537, págs. 370-371. Vivancos M., Silos, n. 102, págs. 156-157. Álamo J. del, Oña, n. 502, págs. 615-617. Pereda, F. J., Catedral de Burgos, n. 98, págs. 140-141); cabillo general, dentro en el cabildo de Santa Maria (PEREDA, F. J., Catedral de Burgos, n. 60, págs. 82-85); “ubi moris est celebrare capitulum... presente capitulo burgensis ecclesie" (lbidem, n. 86, págs. 253-254); "en la capilla sobredicha" (Ibidem, n. 263, págs. 325-329); “in capella Sancti Pauli» (Ibidem, n. 340, págs. 70-72). A partir de 1326, las reuniones se celebran en la capilla de Santa Catalina (vid. CASADO, H., op. cit., pág. 31). 
también un dato característico del primer grupo ${ }^{150}$, que aporta, a su vez, la única información de carácter histórico, referida al fallecimiento del rey Enrique I ${ }^{151}$. Siguen siendo muy poco frecuentes la inclusión de festividades religiosas, a pesar del carácter de sus protagonistas y ni siquiera en documentos de régimen interno y de regulación de la vida capitular como son los estatutos y las disposiciones capitulares ${ }^{152}$. Cuando por fallecimiento del titular de la diócesis, ésta se queda vacante y el cabildo actúa en acontecimientos que debían haber sido presididos por el obispo, ello es incluido dentro de la data ${ }^{153}$.

La tercera diferencia es la que, a nuestro entender, resulta más decisiva y viene referida al sistema de expresión de los años. Parece que la utilización del anno Domini ${ }^{154}$, casi general a partir de 1245 , está directamente relacionada con la expedición en esa oficina del cabildo eclesiástico de Burgos, a veces acompañado de la era híspánica ${ }^{155}$. Sólo uno, de casi finales de siglo y que también consideramos como producción del cabildo, ha utilizado la era exclusivamente ${ }^{156}$. Los documentos de la primera época han expresado los años mediante el tradicional cómputo de la citada era hispánica.

Respecto a las "suscripciones" finales, a excepción de ciertas corroboraciones protagonizadas por el obispo burgalés ${ }^{157}$, el alcalde de la ciudad ${ }^{158}$ y el abad y monasterio de Covarrubias ${ }^{159}$, a las que hay que añadir la relación, más bien prolija, de los testigos, hemos de indicar una vez más una realidad distinta entre ambos grupos. Los primeros vienen caracterizados, precisamente, por la validación de su autor material que, sin

150 Garrico, J. M., Catedral de Burgos, n. 348, pág. 138; n. 391, págs. 185-186; n. 392, pág 187 ; n. 400 , págs. $195-196$; n. 413 , págs. $209-210$; n. 422 , págs. $220-221$; n. 471 , págs. 284-285; n. 493, págs. 311-312, n. 500, págs. 319-320; n. 513, págs. 335-336. PEREDA, F. J., Catedral de Burgos, n. 60 , págs. $82-85 ;$ n. 83 , págs. 119-123. En la documentación episcopal también tiende a desaparecer, en contraposición con la realidad de cronologías anteriores.

151 GaRRIDO, J. M., Catedral de Burgos, n. 509, págs. 330-331

152 Garrido, J. M., Catedral de Burgos, n. 422, págs. 220-221. Pereda F. J., Catedral de Burgos, n. 60 , págs. $82-85$; n. 83 , págs. $119-123$.

153 «Sede burgense sede uacante per mortem bone memorie domini fratri Fernandi, quondam burgensis episcopi» (PEREDA, F. J., Catedral de Burgos, n. 340, págs. 70-72).

154 Álamo, J. del, Oña, n. 502, págs. 615-617. LóPez de Sllanes, C., Calceatense, n. 33, págs. 32-33. Ubieto, A., Cuéllar, n. 17, págs. 47-48. Pereda, F. J., Catedral de Burgos, n. 44, págs. 6465 ; r. 98, págs. $140-141$; n. 99, págs. $141-142$; n. 186, págs. 253-254; n. 263, págs. 325-329; n 278, págs. $349-350 ;$ n. 392 , págs. $177-185$; n. 340 , págs. $70-72$; n. 342 , págs. $75-76$; n. 344 , págs. $78-79$; n. 346, págs. 80-81. Serrano L., Covarrubias, n. 77, págs. 120-121.

155 Pereda, F. J., Catedral de Burgos, n. 60, págs. 82-85; n. 83, págs. 119-123.

156 Ibidem, n. 313, págs. 36-38.

157 Ibidem, n. 60 , págs. $82-85 ;$ n. 83 , págs. 119-123.

158 Ibidem, n. 60 , págs. 82-85.

159 lbidem, n. 83, págs. 119-123. 
título alguno, y con una escueta expresión de nombre y actuación, cierra los documentos ${ }^{160}$. Los segundos, validados mediante sello, como ya hemos indicado, excepcionalmente vienen acompañados del nombre de sus autores materiales y algunos se autodenominan escribanos públicos de la ciudad ${ }^{161}$.

Ya hemos llamado la atención, por último, sobre las 51 suscripciones y sellos que aseguran los citados acuerdos tomados por el cabildo catedralicio en $1291{ }^{162}$. Aunque no se conserva el original, el anuncio de validación y sobre todo cada suscripción acompaña, al nombre y dignidad, su autografía y la aposición de su propio sello particular - «propia manu subscripsi et sigillum meum apposui»-, además del sello del cabildo. Dispuestas en columnas de desigual número, en la primera, la más nutrida -25-, suscriben el deán, el cantor, sacristán, los abades de Foncea, Cervatos, $\mathrm{S}$. Millán y Santa Juliana, doce canónigos, cinco porcioneros y un socio. En la segunda y cuarta columna, dos socios en cada una. En la tercera, con 22 suscripciones, se encuentra la de los arcedianos de Burgos, de Lara y de Palenzuela, los abades de Castro, S. Quirce y Salas de los Infantes, once canónigos, imprime, sin duda, al documento mayor solemnidad. Otro documento que también destaca por el número y disposición de los testigos es la aprobación y promesa de cumplimiento de las constituciones dadas al cabildo burgalés, ya que son nombrados casi todos los miembros del mismo y, al, parecer, según la disposición observada a la hora de los oficios divinos. Su número asciende, igualmente, a $51^{163}$.

En estos documentos protagonizados por el cabildo catedralicio detectamos, como hemos intentado poner de relieve en su análisis, una mayor

150 "lohannes de Riolazedo" (GARRIDo, J. M., Catedral de Burgos, n. 348, pág. 138; n. 379, págs. $173-174$; n. 389 , págs. $182-183$; n. 391, págs. $185-186$; n. 392, pág. 187; n. 400, págs. $195-$ 196). "Nicholaus y Nicholaus Martini" (Serrano, L., Obispado de Burgos, n. 240, págs. 363-364; n. 241, págs. 364-365. GARRIDO, J. M., Catedral de Burgos, n. 410, págs. 206-207; n. 411, págs. 207-208; n. 412, págs. 208-209; n. 413, págs. 209-210; n. 422, págs. 220-221; n. 430; págs. 234 235; n. 471, págs. 284-285; n. 482, págs. 297-298; n. 486, págs. 301-302; n. 493, págs. 311-312; n. 495 , págs. $313-314$; n. 498 , pág. 317 ; n. 500 , págs. $319-320$; n. 508 , pág. 329 ; n. 509 , págs. 330-331; n. 513, págs. 335-336; n. 523, págs. 351-352). Dionisius (lbidem, n. 421, pág. 219). "lohannes Petri» (lbidem, n. 545, págs. 385-386. PeREDA, F. J., Catedral de Burgos, n. 60, págs. 82-85).

r6r "Bartholomeus, clericus burgensis" (Álamo, J. del, Oña, n. 502, págs. 615-617). "Lucas Gonçález, escriuano público de Burgos" (PERedA, F. J., Catedral de Burgos, n. 83, págs. 119123). "Pedro Martínez» (Ibidem, n. 392, págs. 177-185). «lohannes Gundissalui, publicus in ciuitate et diocesi burgensis regia auctoritate notarius iuratus" (Ibidem, n. 340, págs. 70-72; n. 344, págs. 78-79).

162 Ibidem, n. 263, págs. 325-329.

163 Pereda, F. J., Catedral de Burgos, n. 98, págs. 140-141. 
precisión y caracterización formulística, en cuanto a la utilización de una u otras fórmulas que sirven para caracterizar la producción capitular de esta época. Si combinamos los criterios de suscripción o no de autor material, podemos deducir fácilmente que su presencia va relacionada con el inicio invocativo y con la elaboración de los mismos fuera del ámbito catedralicio. Su ausencia va directamente relacionada con la utilización del sello como medio de validación y, por consiguiente, con su ejecución dentro de dicha oficina de expedición. Por contra, la forma habitual de inicio de éstos es la notificativa. Los hay también que presentan ambos sistemas, sello y suscripción, y otros que carecen de cualquier medio validatorio:

\section{DOCUMENTOS SUSCRITOS}

Iniciados por la INVOCACIÓN

Censo

Confirmación de elección de prior

Dotación de capellanía

Permuta

Prestimonio

Reconocimiento de prestimonio

Venta

Iniciados por la NOTIFICACIÓN

Donación

Permuta

Iniciados por la INTITULACIÓN

Prestimonio

Iniciados por la DATA

Sentencia

\section{DOCUMENTOS SELLADOS}

Iniciados por la NOTIFICACIÓN

Absolución

Acuerdos capitulares

Aprobación y promesa de cumplimiento

Certificación de traslado

Compromiso

Ordenamiento

Sentencia arbitral 


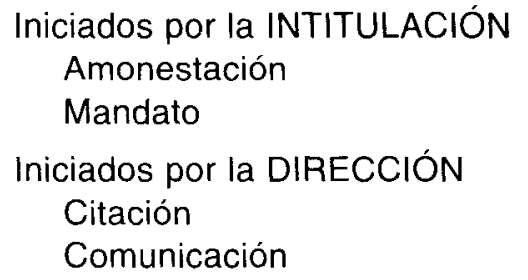

\title{
DOCUMENTOS SELLADOS Y SUSCRITOS
}

Iniciados por la INVOCACIÓN

Avenencia

Iniciados por la NOTIFICACIÓN

Venta

Iniciados por la NARRACIÓN

Prórroga para dirimir una contienda

\section{DOCUMENTOS NO SUSCRITOS NI SELLADOS}

\author{
Iniciados por la INVOCACIÓN \\ Dotación de capellanía \\ Iniciados por la NOTIFICACIÓN \\ Reconocimiento \\ Iniciados por la DATA \\ Acta de entrega de bienes
}

De su conjunto, se pueden deslindar tres grupos diferentes. Uno, para los referidos a negocios de ámbito privado y relacionados con la enajenación total o transitoria de bienes, cuya propiedad pertenecia al cabildo o bien le era entregada. Me refiero al conjunto de ventas, permutas, censos y prestimonios que se conservan, procedentes, la mayoría, de las dos primeras décadas de esta centuria. Su confección, como ya hemos reiterado, estuvo vinculada a personas que ponían por escrito los negocios de otros vecinos de la ciudad y carentes de una relación personal y directa con este cabildo.

Otro, para los relacionados con la actuación judicial y resolutoria de conflictos por parte de este cabildo burgalés. Estos, más singulares que los anteriores, no sólo por su contenido, sino también por su forma de 
expedición, son fruto de esta escribanía propia. Entran en él las sentencias, compromisos, avenencias y absoluciones, que, como resulta lógico, suelen llevar el sello como medio de validación. A veces, de redacción objetiva y con amplias narraciones, son reflejo de sus competencias eclesiásticas y constituyen el equivalente a esa intensa labor judicial protagonizada por el titular de la diócesis, bastante notable en época del tan mencionado obispo D. Mauricio. Se pueden incluir aquellos otros que favorecen o completan estas funciones, tales como las citaciones, prórrogas para dirimir una contienda y amonestaciones.

Un tercer grupo estaría integrado por los de régimen interno, que, como constituciones capitulares, su aprobación y promesa de cumplimiento, así como otros similares, reflejan y regulan la organización y modos de comportamiento del cabildo capitular. También son producto de esa oficina propia. Quizá es en ellos donde se puedan detectar mayores elementos de solemnidad en cuanto a la utilización de ciertas formas protocolarias, que casi empiezan a caer en desuso, y, sobre todo, un mayor número de suscripciones de las dignidades y demás componentes de la iglesia catedral de Burgos.

Evidentemente, hay otros documentos que se escapan a estos tres apartados, pero no por ello dejan de ser producto de esta escribanía capitular. Entre ellos, la costumbre de certificar o trasladar otros, normalmente pontificios, que sin ninguna duda han sido elaborados en ella, ya que muestran un formulario idéntico y propio de este ámbito concreto, aparte de su validación mediante sello.

A lo largo de este recorrido por la documentación capitular de la diócesis burgalesa he intentado poner de manifiesto la existencia de una oficina de expedición para los documentos protagonizados o intitulados por este cabildo en su conjunto o por alguna de sus dignidades en particular. Ello es algo que se vislumbra con relativa facilidad a medida que avanza el siglo xill. Se podría precisar que su punto de partida coincide con el episcopado de D. Mauricio y como fecha inicial, a tenor de las fuentes corısultadas y conservadas, puedo señalar 1222. A partir de entonces, la mayoría de los documentos que se nos han transmitido han sido producto de dicha oficina.

¿Qué elementos, externos e internos, sirven de pauta para su identificación? Con todas las cautelas que este asunto requiere y aún convencida 
de que la documentación del siglo xIV puede ser mucho más definitoria, indicaría los siguientes aspectos:

- Sello como principal, a veces único, elemento de validación.

- Frecuente ausencia del nombre del autor material.

- Uso predominante del latín como medio de expresión.

- Utilización del Anno Domini, sólo o acompañado del tradicional sistema de la era hispánica, para el cómputo de los años.

- Inclusión del anuncio de validación en el tenor documental.

Otra cuestión diferente es la existencia o no de una oficina de expedición para el obispo de la diócesis y otra distinta para el cabildo. Es éste un aspecto importante y, aunque creemos en la realidad de ambas, no es fácil concluir una total separación entre una y otra. De la primera, tampoco hay muchas noticias, pero pensamos que alrededor del obispo unos clérigos, con una relación más cercana con el titular de la sede, fueron los encargados de su producción documental. Cabría preguntarse, además, por quién o en dónde fueron confeccionados los documentos intitulados conjuntamente por el obispo y por el cabildo, provistos con ambos sellos. Nos inclinamos a suponer que la escribanía capitular tuviera un mayor protagonismo en tal circunstancia, pero es algo que habria que comprobar y constatar. En todo caso, no dudamos que el análisis de lo ocurrido durante el siglo XIV ayudaría a clarificar éstos y otros aspectos relativos al hecho documental de esta diócesis castellana.

Escribanía capitular de la catedral de Burgos, escribanía episcopal de su titular. Dos realidades a partir del mandato de D. Mauricio. Su inicio, como en otros ámbitos de la documentación, coincide con la difusión del hecho escriturario en la corona castellana y con el reconocimiento de la plasmación de derechos. Esperemos que análisis diplomáticos de otras sedes episcopales permitan, en breve, llevar a cabo estudios comparativos dentro de este marco eclesiástico y, a la vez, con la documentación producida por la cancillería de los reyes castellano-leoneses y por el notariado de las diferentes ciudades y villas de estos reinos. 